\title{
Investigation of skin infection frequency in Turkish wrestlers
}

\section{Türk güreșçilerde deri enfeksiyonları sıklığının araștırılması}

\section{Ömer Kaynar, Ragıp İsmail Engin*, Fikret Dağdeviren**, Mikail Yılmaz***, Bora Özkan****, Sadık Öztürk*****}

\author{
Muș Alparslan University, Faculty of Physical Education and Sport, Muș, Turkey \\ *Erzurum Regional Training and Research Hospital, Clinic of Dermatology, Erzurum, Turkey \\ **Inönü University Faculty of Physical Education and Sport, Malatya, Turkey \\ ***Muș Public Hospital, Clinic of Dermatology, Muș, Turkey \\ ****Mustafa Kemal University Faculty of Medicine, Department of Parasitology, Hatay, Turkey \\ *****Sultanbeyli Public Hospital, Clinic of Dermatology, İstanbul, Turkey
}

\begin{abstract}
Background and Design: The aim of this study was to determine the frequency of dermatological infections among Turkish wrestlers. Materials and Methods: We included 202 wrestlers from different regions of Turkey who volunteered to participate in the study. The "Athlete Biography and Dermatologic Examination Findings" survey that was designed before the research was completed during dermatological examination and dermatologic findings of each athlete were evaluated.

Results: During the physical examination of 202 Turkish wrestlers, 115 (57\%) of participants were observed to have skin infection while no skin infection was found in $87(43 \%)$. It has been detected that these infections were fungal, bacterial and viral in $31 \%, 18 \%$ and $8 \%$ of patients, respectively. The rates of infections were $25(12 \%), 28(14 \%), 15(8 \%), 12(6 \%), 12(6 \%), 8(4 \%), 6(3 \%), 5(2 \%), 2(1 \%)$, and $2(1 \%)$ for tinea corporis, tinea pedis, erythrasma, folliculitis, wart, onychomycosis, paronychia, herpes, impetigo, and tinea versicolor, respectively. Conclusion: In this study, it was found that Turkish wrestlers had skin infections, these infections were not as common as reported in the literature. It can be understood that early diagnosis and treatment is very important in reducing the prevalence of these infections in wrestlers. Keywords: Sport, wrestling, skin infections
\end{abstract}

Öz

Amaç: Bu araştırmanın amacı Türk güreşçilerde görülen dermatolojik enfeksiyonların sıklı̆ını belirlemektir. Gereç ve Yöntem: Araştırmaya Türkiye'nin farklı illerindeki spor kulüplerinde aktif olarak güreş yapan 202 gönüllü sporcu katıldı. Araştırmaya başlamadan önce hazırlanan "Sporcu Geçmişi ve Dermatolojik Muayene Bulguları" anketindeki sorular dermatolog tarafından sporculara muayene edildiği sırada soruldu ve her bir güreş̧̧inin muayene bulguları bu anket formuna kaydedildikleri değerlendirildi.

Bulgular: Çalışmamızda yer alan 202 Türk güreşçinin fiziksel muayenesi sırasında 115'inde (\%57) deri enfeksiyonları görüldüğü, 87'sinde (\%43) ise deri enfeksiyonlarının görülmediği tespit edildi. Bu enfeksiyonların sırayla mantar, bakteri ve virüs kaynaklı \%31, \%18 ve \%8 olduğu tespit edildi. Enfeksiyon oranları sırayla tinea korporis, tinea pedis, eritrazma, follikülit, verrü, onikomikoz, paronişi, herpes, impetigo ve tinea versikolor, 25 (\%12), 28 (\%14), 15 (\%8), 12 (\%6), 12 (\%6), 8 (\%4) 6 (\%3), 5 (\%2), 2 (\%1) ve 2 (\%1) teşhis edildi.

Sonuç: Çalışmamızda Türk güreşçilerinde deri enfeksiyonlarının görüldüğü fakat deri enfeksiyonlarının literatür bulgularında yer aldığı kadar yaygın olmadığı anlaşılmaktadır. Güreşçilerde bu enfeksiyonların görülme sıklığını azaltmak için erken tanı ve tedavinin çok önemli olduğu anlaşılmaktadır.

Anahtar Kelimeler: Spor, güreş, deri enfeksiyonları

Address for Correspondence/Yazışma Adresi: Ömer Kaynar MD, Muș Alparslan University, Faculty of Physical Education and Sport, Muș, Turkey Phone.: +90 5327751749 E-mail: omer_kaynar49@hotmail.com ORCID-ID: orcid.org/0000-0002-5676-3627 Received/Geliş Tarihi: 11.07.2016 Accepted/Kabul Tarihi: 14.02.2017

This study was orally presented at 14 $4^{\text {th }}$ International Sports Sciences Congress held in Antalya Belek on 1-4 December 2016.

c Copyright 2017 by Turkish Society of Dermatology and Venereology

Turkderm-Turkish Archives of Dermatology and Venereology published by Galenos Yayınevi. 


\section{Introduction}

Skin infections are one of the important health problems for athletes in contact sports. Especially in wrestling, skin infections can easily occur as a result of skin-to-skin contact. Therefore, skin infections are common in wrestlers ${ }^{1,2}$.

In their study conducted on wrestlers, Kohl et al. ${ }^{3}$ reported the rates of $42 \%, 11 \%$, and $85 \%$ for impetigo, herpes and fungal infections, respectively. It has been reported that the most bacterial skin infections occurred in judo team at a university in Japan ${ }^{4}$, while one third of a high level judo team of 131 members in France carried tinea corporis gladiatorum ${ }^{5}$.

It was found that an athlete with skin infection may possibly transmit the infection to other teammates and this could lead to impaired exercise performance at the rate of $10-15 \%$. Therefore, apart from being an important health problem, skin infections also adversely affect athletes' performance ${ }^{6,7}$.

This study aimed to detect the frequency of skin infections among wrestlers in Turkey and to contribute to reducing risk factors for skin infections.

\section{Materials and Methods}

A total of 202 volunteer wrestlers from sports clubs in various provinces of Turkey participated in the study. Dermatological examination was held by dermatologists in either sports halls or dermatology departments of hospitals.

The Athlete Background and Dermatologic Examination Findings questionnaire was prepared prior to the research in order to detect the frequency of skin infection in wrestlers. In this questionnaire, dermatologists asked the questions to the wrestlers during the examination and dermatologic examination findings of each wrestler were recorded in this questionnaire form.

Dermatologic examination of the wrestlers was conducted in detail by dermatologists. In this study, it was aimed to detect the prevalence of skin infections such as tinea corporis, tinea versicolor, tinea pedis and nail fungus, herpes, verruca, folliculitis, impetigo and erythrasma in wrestlers. For this study, approval of Ethical Committee of Clinical Research, Faculty of Medicine at Atatürk University was obtained (Decision no: 37/7) and the volunteers were informed about the study both written and orally and their approval was received prior to the research. For statistical analysis, SPSS version 22 was used to compare the differences between the results obtained from chi-square test and variance analysis.

\section{Results}

Characteristics of wrestlers included in the study are presented in Table 1 (arithmetic mean, standard deviation, minimum and maximum values of age, weight, height, body mass index).

Dermatologic examination was conducted by seven dermatologists in 202 volunteer wrestlers from various provinces of Turkey. The mean age of the participants was 17.57 years (range: 11-38).

During the physical examination in 202 Turkish wrestlers, skin infections were observed in 115 (57\%) and not observed in 87 (43\%) participants. It has been detected that the sources of these infections were fungi, bacteria and viral (31\%, $18 \%$ and $8 \%$, respectively). The rates of infections in wrestlers were 25 (12\%), 28 (14\%), 15 (8\%), 12 (6\%), $12(6 \%), 8(4 \%) 6(3 \%), 5(2 \%), 2(1 \%)$, and 2 (1\%) for tinea corporis, tinea pedis, erythrasma, folliculitis, wart, onychomycosis, paronychia, herpes, impetigo and tinea versicolor, respectively (Table 2). Though the infection rate was high only $17(8.4 \%)$ of the patients had consulted a physician, it was found that 53 (26.0\%) of wrestlers developed skin infection after they started wrestling.

Skin infection findings of the wrestlers (the level of the wrestlers, age groups and skin infections) included in this study are presented in Table 3. A statistically significant difference was found between national and non-national team wrestlers in the frequency of tinea pedis, tinea corporis, and consulting a doctor. There was also a statistically significant difference between the age groups in the frequency of tinea corporis, erythrasma, medical examination, and consulting a doctor $(p<0.05)$ (Table 3).

\section{Discussion}

There are many studies conducted on adverse effects of skin infections in athletes in the literature. Skin infections can be found in many sports such as wrestling, football, boxing, athleticism, karate, and swimming. It is known that the prevalence of skin infections in wrestlers is higher compared to that in athletes in other sports. Researches emphasize that skin infections are among common health problems in athletes, especially in wrestlers ${ }^{2,5,8,9}$. In parallel with these studies, the present study also reported bacterial, fungal and viral skin infections in Turkish wrestlers, however, these infections were not as common as reported in the literature for Turkish wrestlers.

Table 1. Physical features of the wrestlers

\begin{tabular}{|l|l|}
\hline Physical Features & Mean $( \pm$ SD) (min.- max.) \\
\hline Age (year) & $17.54( \pm 4.75)(11-38)$ \\
\hline Weight $(\mathrm{kg})$ & $62.86( \pm 18.43)(27-123)$ \\
\hline Height $(\mathrm{m})$ & $166.24( \pm 12.65)(1.35-1.85)$ \\
\hline BMI* & $22.42( \pm 4.25)(13.79-38.82)$ \\
\hline *BMI: Body mass index, SD: Standard deviation, min.: Minimum, max.: Maximum \\
\hline
\end{tabular}

Table 2. Skin infection findings of the wrestlers (n/\%)

\begin{tabular}{|l|l|}
\hline Skin infections & $(\mathbf{n} / \%)$ \\
\hline Tinea corporis & $25(12)$ \\
\hline Tinea pedis & $28(14)$ \\
\hline Erythrasma & $15(8)$ \\
\hline Folliculitis & $12(6)$ \\
\hline Verruca & $12(6)$ \\
\hline Onychomycosis & $8(4)$ \\
\hline Acronyx & $6(3)$ \\
\hline Herpes & $5(2)$ \\
\hline Impetigo & $2(1)$ \\
\hline Tinea versicolor & $2(1)$ \\
\hline Skin infections seen & $115(57)$ \\
\hline Skin infections is not seen & $87(43)$ \\
\hline
\end{tabular}


Table 3. Skin infection findings of the wrestlers (wrestler type, age groups and infection)

\begin{tabular}{|c|c|c|c|c|c|c|c|}
\hline & \multicolumn{5}{|c|}{ Wrestler Type } & & \\
\hline & \multicolumn{3}{|c|}{ National } & \multicolumn{2}{|c|}{ Non-National } & \multirow[t]{2}{*}{ Total } & \multirow[t]{2}{*}{$\mathbf{P}$} \\
\hline & \multicolumn{2}{|l|}{$\mathbf{n}$} & $\%$ & $\mathbf{n}$ & $\%$ & & \\
\hline Tinea corporis & \multicolumn{2}{|l|}{0} & 0 & 25 & 100 & 25 & 0.014 \\
\hline Tinea pedis & \multicolumn{2}{|l|}{8} & 33.3 & 16 & 66.7 & 24 & 0.013 \\
\hline \multirow[t]{4}{*}{ Application to doctor* } & \multicolumn{2}{|l|}{6} & 35.3 & 11 & 67.4 & 17 & 0.025 \\
\hline & \multicolumn{5}{|c|}{ Age Groups \& Skin Infection } & & \\
\hline & \multicolumn{2}{|c|}{ Below 18} & & \multicolumn{2}{|c|}{ Above 18} & Total & $\mathbf{p}$ \\
\hline & $\mathbf{n}$ & $\%$ & $\mathbf{n}$ & \multicolumn{2}{|l|}{$\%$} & & \\
\hline Erythrasma & 4 & 26.7 & 11 & \multicolumn{2}{|l|}{73.3} & 15 & 0.034 \\
\hline Medical examination** & 14 & 35.9 & 25 & \multicolumn{2}{|l|}{64.1} & 39 & 0.016 \\
\hline Application to doctor* & 6 & 35.3 & 11 & \multicolumn{2}{|l|}{64.7} & 17 & 0.011 \\
\hline Tinea corporis & 6 & 25.0 & 18 & \multicolumn{2}{|l|}{75} & 24 & 0.04 \\
\hline
\end{tabular}

In a study by Ashack et al. ${ }^{10}$ conducted on athletes of various sports, such as wrestling, football, ice hockey, volleyball, basketball and swimming. Skin infections were found mostly in wrestlers with the rate of $17.9 \%$, while this rate was $1.2 \%$ for those in other sports branches. It was reported that the most contaminating organisms causing skin infection were bacteria with $53.8 \%$, fungi with $35.7 \%$ and viruses with $6.7 \%$. In the present study, it was detected that the types of infectious agents were fungi, bacteria and viruses in $31 \%, 18 \%$ and $8 \%$ of subjects, respectively.

Especially, fungal skin infections were found to be common in wrestlers due to skin-to-skin contact ${ }^{11,12}$. The rates of reported fungal skin infections in Turkish wrestlers varied between $20 \%$ and $85 \% 3,8,11$.

In a study conducted on 137 football players in Turkey, 38 (27.7\%) had clinically suspected fungal lesions ${ }^{13}$. In another study conducted in Turkey, skin infections were detected in 28 (11.9\%) out of 236 Turkish swimmers during dermatologic examinations and the most common skin infection was detected to be tinea pedis $15(6.4 \%)^{14}$.

In a cross-sectional study conducted on American wrestlers, the rate of tinea corporis gladiatorum was found to be $24 \%{ }^{15}$. In another study, it was reported that suspected fungal infections were found in $24.5 \%$ of 454 wrestlers; and malassezia furfur and trichophyton tonsurans fungus were isolated in the samples taken from these lesions in the rate of $50 \%{ }^{16}$. It was found that tinea corporis was common in beginner wrestlers ${ }^{17}$.

In a study by the National Athletic Trainers' Association conducted on college wrestlers, it was reported that one fourth of college wrestlers were affected by at least one type of skin diseases, and this effect was mostly from fungal infections (11.4\%), as it was also shown in our study. It was found that fungal infections were one of the three most common skin infections (bacterial, viral, fungal) in wrestlers. The rates were as follows, 83.8, 6.8, 3.4, 1.7, and 3.4\% for fungal infections, impetigo, dermatitis, herpes zoster and other skin infections, respectively ${ }^{18}$.

In a study conducted on 411 wrestlers in Tehran, it was reported that the rate of athletes consulting a doctor for skin diseases was around $52 \%$. It was found that fungal infections affecting $47.4 \%$ of all athletes were the most common skin infections while herpes gladiatorum affecting 3.2\% was the least common infection ${ }^{6}$. In the present study, it was found that $57 \%$ of 202 Turkish wrestlers had skin infections detected during medical examination and the infections were caused by fungi, bacteria and viruses in $31 \%, 18 \%$ and $8 \%$ of subjects, respectively. However, the rate of those who consulted a doctor was $8 \%$ which should be taken into consideration for the health of athletes. Bacterial skin infections were the second most common type of infection following fungal infections in wrestlers. In different studies, different rates were reported for impetigo as high as 42-46\%3,19,20.

Tinea corporis (tinea gladiatorum) and herpes simplex virus infections are very common especially in beginner wrestlers ${ }^{21,22}$.

In a research conducted by Ertam et al. ${ }^{14}$ in swimmers, it was found that skin diseases were mostly found in athletes aged 18 years and older (35.7\%). Furthermore, an increase was found in fungal-derived skin diseases, such as tinea pedis and pityriasis versicolor, as the age increases. It was observed that age was positively correlated with longer time in pool and more direct contact between feet and pool environment. Warm and humid contribute to increased prevalence of tinea pedis and pityriasis versicolor

In contrast to the findings of the study by Ertam et al. ${ }^{14}$, the present study showed that the prevalence of skin infections decreased with age in wrestlers. The reasons of infections in athletes who have started wrestling in early ages are believed to be temperature, humid environment, poor hygiene and lack of knowledge about fighting against them. Therefore, beginner wrestlers must pay attention to follow hygiene rules and trainers must endeavor to teach these rules to wrestlers.

In addition, in the present study, the prevalence of skin infections in national athletes was found to be lower compared to that in nonnational athletes. Comparing the age of national wrestlers with that of non-national wrestlers, non-national wrestlers were found to be younger. In the literature, it has been reported that herpes simplex and tinea corporis were common in beginner wrestlers ${ }^{17}$, supporting the findings of the present study. It was also assumed in the present study that younger wrestlers attend skin examination by a doctor more frequently than older ones. 
Taking stand from the finding that the prevalence of skin infections was higher in wrestlers ${ }^{23}$, to take measures to prevent skin infections, which adversely affect achievements of wrestlers in sports, ${ }^{23,24}$ is recommended.

As can be understood from the present study and previous studies, fungal infections and especially tinea corporis are the most commonly found skin infections in wrestlers. As is known, fungal infections may lead to itching symptoms and can be very irritating, therefore, they cause a significant loss of motivation during sport activities in wrestlers as well as in many people in working life. It can be said that wrestlers must be informed about consulting a dermatologist at least when they have suspected skin infection, in order to protect their health and sportive performance.

\section{Conclusion}

In this study, it was found that Turkish wrestlers had skin infections and these infections were not as common as reported in the literature. It can be understood that early diagnosis and treatment are very important in reducing the prevalence of these infections among wrestlers and to increase their performance.

\section{Ethics}

Ethics Committee Approval and Informed Consent: For this study, approval of Ethical Committee of Clinical Research, Faculty of Medicine at Atatürk University was obtained (Decision no: 37/7) and the volunteers were informed about the study both written and orally and their approval was received prior to the research.

Peer-review: Externally and Internally peer-reviewed.

\section{Authorship Contributions}

Surgical and Medical Practices: Ö.K., R.I.E., F.D., M.Y., B.Ö., S.Ö., Concept: Ö.K., R.I.E., F.D., M.Y., B.Ö., S.Ö., Design: Ö.K., R.I.E., F.D., M.Y., B.Ö., S.Ö., Data Collection or Processing: Ö.K., R.I.E., F.D., M.Y., B.Ö., S.Ö., Analysis or Interpretation: Ö.K., R.I.E., F.D., M.Y., B.Ö., S.Ö., Literature Search: Ö.K., R.I.E., F.D., M.Y., B.Ö., S.Ö., Writing: Ö.K., R.I.E., F.D., M.Y., B.Ö., S.Ö.

Conflict of Interest: No conflict of interest was declared by the authors.

Financial Disclosure: The authors declared that this study received no financial support.

\section{References}

1. Kordi R, Ziaee V, Rostami M, Wallace W: Sports injuries and health problems among wrestlers in Tehran. J Pak Med Assoc 2012;62:204-8.

2. Mysnyk MC: Wrestling. Ed: Fu FH, Stone DA. Sports injuries: mechanisms, prevention, treatment. 2nd edition. Philadelphia, Pa. London, Lippincott Williams \&Wilkins; 2001;818-38.
3. Kohl TD, Giesen DP, Moyer JJ, Lisney MT: Tinea gladiatorum: Pennsylvania's experience. Clinical J Sports Med 2002;12:165-71.

4. Shiraki $Y$, Soda $N$, Hirose $N$, Hiruma M: Screening examination and management of dermatophytosis by trichophyton tonsurans in the judo club of a university. Nihon Ishinkin Gakkai Zasshi 2004;45:7-12.

5. Poisson DM, Rousseau $D$, Defo $D$, Estève EOutbreak of tinea corporis gladiatorum, a fungal skin infection due to Trichophyton tonsurans, in a French high level judo team. Euro Surveill 2005;10:187-90.

6. Kordi R, Mansournia MA, Nourian RA, Wallace WA: Cauliflower ear and skin infections among wrestlers in Tehran. J Sports Sci Med 2007;6:39-44.

7. Hazen $P G$, Weil ML: Itraconazole in the prevention and management of dermatophytosis in competitive wrestlers. J Am Acad Dermatol 1997;36:4812 .

8. Landry GL, Chang CJ: Herpes and tinea in wrestling: managing outbreaks, knowing when to disqualify. Phys Sportsmed. 2004;32:34-41.

9. Agel J, Ransone J, Dick R, Oppliger R, Marshall SW: Descriptive epidemiology of collegiate men's wrestling injuries: National Collegiate Athletic Association Injury Surveillance System, 1988-1989 through 2003-2004. J Athl Train 2007;42:303-10.

10. Ashack KA, Burton KA, Johnson TR, Currie DW, Comstock RD, Dellavalle RP: Skin infections among US high school athletes: A national survey. Am Acad Dermatol 2016;74:679-84.

11. Adams BB: Dermatologic disorders of the athlete. Sports Med 2002;32:30921.

12. Beller M, Gessner BD: An outbreak of tinea corporis gladiatorum on a high school wrestling team. J Am Acad Dermatol 1994;31:197-201.

13. Ergün $M$, Ertam I, Aytimur $D$, İşlegen Ç, Erboz S: Futbolcularda yüzeyel mantar enfeksiyonu sıklı̆ının araştıııması. Turkderm 2001;35:312-4.

14. Ertam I, Ergün M, Aytimur $D$, Babür Y: Yüzme sporu yapanlarda deri bulgularının havuza devam süresi ile ilişkisi. Turkderm 2003;37:274-7.

15. Adams BB: Tinea corporis gladiatorum: a cross-sectional study. J Am Acad Dermatol 2000;43:1039-41.

16. Ahmadinejad Z, Razaghi A, Noori A, Hashemi SJ, Asghari R, Ziaee V: Prevalence of fungal skin infections in Iranian wrestlers. Asian J Sports Med 2013;4:29-33.

17. el Fari $M$, Graser $Y$, Presber W, Tietz HJ: An epidemic of tinea corporis caused by trichophyton tonsurans among children (wrestlers) in Germany. Mycoses 2000;43:191-6.

18. NATA (TheNationalAthleticTrainers' Association). (2003) Injury surveillance study. The National Athletic Trainers' Association. Available from URL: http:// www.nata.org [Accessed 19.11.2003].

19. Williams C, Wells J, Klein R, Sylvester T, Sunenshine R; Centers for Disease Control and Prevention (CDC): Notes from the field: outbreak of skin lesions among high school wrestlers. Arizona, 2014. MMWR Morb Mortal Wkly Rep 2015;64:559-60.

20. Pasque $C B$, Hewett TE: A prospective study of high school wrestling injuries. Am J Sports Med 2000;28:509-15.

21. Belongia EA, Goodman JL, Holland EJ, et al: An outbreak of herpes gladiatorum at a high school wrestling camp. N Engl J Med 1991;325:90610.

22. Beck CK: Infectious diseases in sports. Medicine\&Science in Sports \&Exercise 2000:32:431-8.

23. Pedersen M, Doyle MR, Beste A, Diekema DJ, Zimmerman MB, Herwaldt LA: Survey of high school athletic programs in lowa regarding infections and infection prevention policies and practices. lowa Orthop J 2013;33:107-13.

24. Anderson BJ: Effectiveness of body wipes as an adjuncttor educing skin infections in high school wrestlers. Clin J Sport Med 2012;22:424-9. 